\title{
The Renal Response to Acid Loads in Metabolic Alkalosis; An Assessment of the Mechanisms Regulating Acid Excretion *
}

\author{
Richard L. Tannen, $\dagger$ Howard L. Bleich, $\dagger$ and William B. Schwartz $\vdots$ \\ (From the Department of Medicine, Tufts University School of Medicine, and the Renal \\ Laboratory, New England Medical Center Hospitals, Boston, Mass.)
}

It is widely recognized that in chronic metabolic alkalosis acid excretion persists despite the alkalinity of the extracellular fluid. In most instances this paradoxical behavior has been attributed to potassium depletion (1), although depletion of sodium has also been held responsible for restricting the excretion of surplus bicarbonate (2). There have, however, been no systematic attempts to examine critically the factors that regulate acid excretion in the presence of metabolic alkalosis. In the present study, hydrochloric acid and nitric acid were administered to alkalotic dogs under experimental circumstances designed to explore the mechanisms that control excretion of hydrogen.

\section{Methods}

Seventeen balance studies were carried out on $13 \mathrm{fe}-$ male mongrel dogs weighing between 13.1 and $25.3 \mathrm{~kg}$. Before study each dog received commercial dog chow for at least 2 weeks. During each study the dogs were fed approximately $25 \mathrm{~g}$ per $\mathrm{kg}$ per day of a synthetic diet, the composition of which has been described previously (3). The intrinsic electrolyte content of the diet was approximately $1 \mathrm{mEq}$ of sodium, $0.2 \mathrm{mEq}$ of chloride, and $0.1 \mathrm{mEq}$ of potassium per $100 \mathrm{~g}$ of diet. The diet was homogenized with 1.5 times its weight of water and fed in two approximately equal portions daily. Dogs that did not eat spontaneously were fed by tube.

The following technique, similar to that which has been described previously, was employed to induce metabolic alkalosis (4). Dogs were fed the low electrolyte, synthetic diet supplemented with sodium and potassium as the neutral phosphate $\left(4 \mathrm{HPO}_{4} / 1 \mathrm{H}_{2} \mathrm{PO}_{4}\right)$. After 4 days of prefeeding, gastric juice was drained twice each

* Submitted for publication August 24, 1965 ; accepted December 16, 1965.

Supported in part by grants H-759 and HE 5309 from the National Heart Institute.

$\dagger$ Work done during tenure of a postdoctoral research fellowship of the U. S. Public Health Service.

$\ddagger$ Address requests for reprints to Dr. William B. Schwartz, New England Center Hospital, 171 Harrison Ave., Boston, Mass. 02111. day under Histalog 1 stimulation. The sodium chloride and water removed in the gastric juice were refed on the same day, but the small amount of potassium that had been withdrawn was not replaced. (The potassium content of the daily diet was far in excess of the potassium that was withdrawn.) Drainage was continued until plasma bicarbonate concentration increased to a level of 30 to $35 \mathrm{mEq}$ per $\mathrm{L}$; in two instances slightly higher values were inadvertently reached. After a steady state of plasma composition had been achieved, balance observations were made for 4 to 7 days before acid feeding. Thereafter, acid loads, as either hydrochloric or nitric acid, were administered.

Protocol I: hydrochloric acid to alkalotic dogs. $\mathrm{Hy}-$ drochloric acid was added to the daily diet until plasma bicarbonate concentration was restored to its control value. Initially $40 \mathrm{mmoles}$ was given each day, but as the control value was approached, it was necessary in some instances to reduce acid intake to 20 mmoles per day to avoid inducing metabolic acidosis. Balance observations were continued for 5 to 8 days after acid feeding had been discontinued, except in one study on dog 966 in which vomiting occurred on the fourth day.

Two types of electrolyte intake were employed during acid feeding, thus creating two groups within the general protocol. In group IA (five dogs) the daily dietary supplement of 40 mmoles of sodium and 40 mmoles of potassium (as the neutral phosphate) was continued throughout the period of acid feeding and during the period afterwards. In group IB (seven dogs) the sodium and potassium supplement was withdrawn from the diet before the administration of hydrochloric acid; in five of these dogs the electrolyte supplement was withdrawn on the same day that hydrochloric acid administration was begun, and in the remaining dogs the administration of hydrochloric acid was delayed until 7 days after the supplement had been withdrawn.

Protocol II: nitric acid to alkalotic dogs (five dogs). Preliminary studies with nitric acid feeding suggested that metabolic alkalosis would be refractory to sustained correction by nitric acid. For this reason 55 to 58 mmoles of nitric acid, an acid load approximately $50 \%$ larger than that used in the $\mathrm{HCl}$ experiments in Protocol I, was given each day; this dose was continued for 6 days.

In three dogs alkalosis was induced by the technique of

1 Eli Lilly, Indianapolis, Ind. 
gastric drainage described above; in two additional dogs alkalosis was induced by three daily infusions of sodium nitrate, 11 mmoles per $\mathrm{kg}$ per day (5). Since the response to nitric acid was essentially the same in dogs rendered alkalotic by either method, the data from the entire group have been pooled and will be considered together in the remainder of the paper. Throughout these studies, the electrolyte-free diet was supplemented with 2.4 mmoles of potassium and 1.2 mmoles of sodium per $\mathrm{kg}$ of body weight each day as neutral phosphate.

Blood and urine $\mathrm{pH}$ were measured anaerobically at $37^{\circ} \mathrm{C}$ with an Epsco medical blood parameter analyzer. Plasma and urine total carbon dioxide content were determined manometrically. Electrolyte concentrations of diet, stool, and gastric juice were measured on nitric acid extracts. Chloride was measured in plasma, urine, and gastric juice with an Aminco Cotlove chloride titrator and in diet and stool by potentiometric titration with silver nitrate. Nitrogen was determined by the Kjeldahl method, inorganic sulfate gravimetrically as barium sulfate, and organic acids by the method of Van Slyke and Palmer (6). The remaining measurements were made with the Technicon autoanalyzer, with, where necessary, appropriate modifications of the following methods: sodium and potassium by flame photometry; creatinine by the method of Chasson, Grady, and Stanley (7) ; phosphate by the method of Fiske and Subbarow (8); ammonium by the method of Logsdon (9); and nitrate by the method of Engelbrecht and McCoy (10).

Daily balance was calculated as net intake minus combined output in urine, stool, blood, and gastric juice. Each $20 \mathrm{ml}$ of blood was considered to contain $3 \mathrm{mEq}$ of $\mathrm{Na}, 2 \mathrm{mEq}$ of $\mathrm{Cl}$, and $0.6 \mathrm{~g}$ of nitrogen. Potassium balance was corrected for nitrogen balance with a value of $2.7 \mathrm{mEq}$ of potassium for each $\mathrm{g}$ of nitrogen. Titratable acidity was calculated from urine $\mathrm{pH}$, blood $\mathrm{pH}$, and the urinary phosphate content, with a $\mathrm{pK}^{\prime} \mathrm{a}$ of 6.8. Urinary net acid excretion was calculated as ammonium plus titratable acidity minus bicarbonate. Electrolyte and volume shifts were calculated in the usual manner from changes in "chloride space," assuming an initial extracellular fluid (ECF) volume of $20 \%$ of body weight. Bicarbonate concentration and $\mathrm{PCO}_{2}$ were calculated from the Henderson-Hasselbalch equation, assuming a $\mathrm{pK}^{\prime} \mathrm{a}$ of 6.10 , and a solubility coefficient of 0.0301 for blood and 0.0309 for urine. Mean $\mathrm{pH}$ for each group of data was calculated by converting individual $\mathrm{pH}$ determinations to hydrogen ion concentrations, averaging these values, and restoring this average to $\mathrm{pH}$ units. Plasma unmeasured anion concentration was calculated as $\left(\mathrm{Na}^{+}+\mathrm{K}^{+}\right)-$ $\left(\mathrm{Cl}^{-}+\mathrm{HCO}_{8}^{-}+\mathrm{NO}_{3}^{-}\right)$.

\section{Results}

\section{Protocol I: hydrochloric acid to alkalotic dogs}

After gastric drainage and before acid feeding, plasma composition and cumulative electrolyte balances of the dogs used in Protocols IA and IB were virtually identical. Mean cumulative bal- ances were, respectively, chloride, -115 and -104 ; potassium, -111 and -125 ; and sodium, +1 and $+16 \mathrm{mEq}$. In both groups mean plasma potassium concentration was $2.6 \mathrm{mEq}$ per $\mathrm{L}$.

Protocol $I A$. Hydrochloric acid was administered during continued intake of neutral sodium and potassium phosphate (five dogs). A representative study is shown in Figure 1 and Table $I$. Cumulative balance and acid-base data for all dogs are shown in Tables II and III.

Acid-base. Administration of hydrochloric acid induced a significant increase in renal acid excretion that was evident in each dog by the second day of acid administration; plasma bicarbonate concentration at this time was still 3.9 to $7.8 \mathrm{mEq}$ per $\mathrm{L}$ above control levels, and $\mathrm{pH}$ was still at frankly alkaline levels (mean $\mathrm{pH}$ 7.50). The mean cumulative increase in net acid excretion during correction of the alkalosis was $104 \mathrm{mEq}$ (range, 87 to $124 \mathrm{mEq}$ ). This increment was due to a mean increase in cumulative ammonium excretion of $76 \mathrm{mEq}$, in titratable acid excretion of $18 \mathrm{mEq}$, and to a decrease in the small daily excretion of bicarbonate. Mean urine $\mathrm{pH}$ fell from 6.2 to 5.8 .

The administration of an average of 179 mmoles (range, 156 to 195 mmoles) of hydrochloric acid over 4 to 5 days was required to decrease mean plasma bicarbonate concentration from $33.4(\mathrm{pH}$

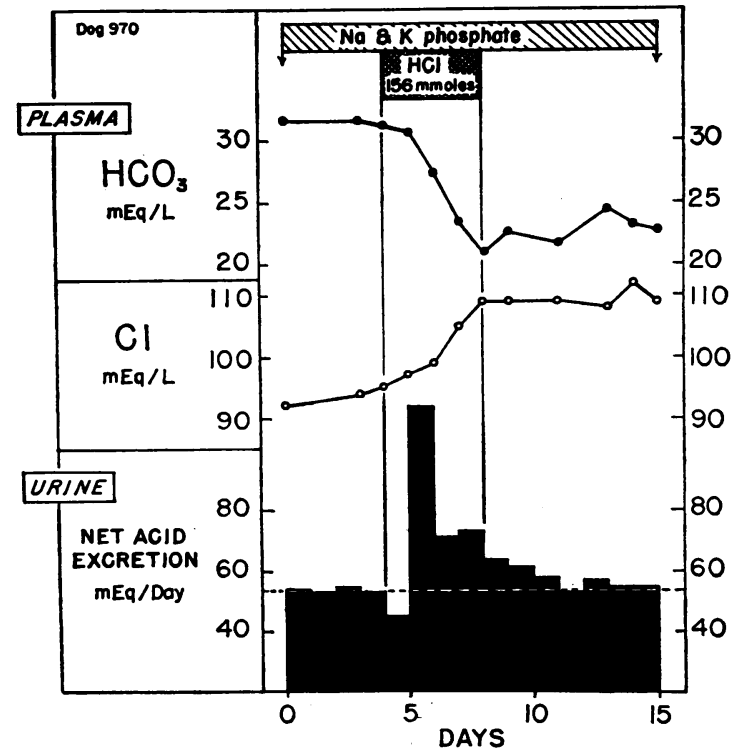

Fig. 1. EFFECTS OF ADMINISTERING HYDROCHLORIC ACID TO AN ALKALOTIC DOG INGESTING A DIET CONTAINING NEUTRAL SODIUM AND POTASSIUM PHOSPHATE. 
TABLE I

Balance data on an alkalotic dog fed hydrochloric acid (39 mmoles/day) while ingesting a diet containing sodium and potassium phosphate (no. 970)

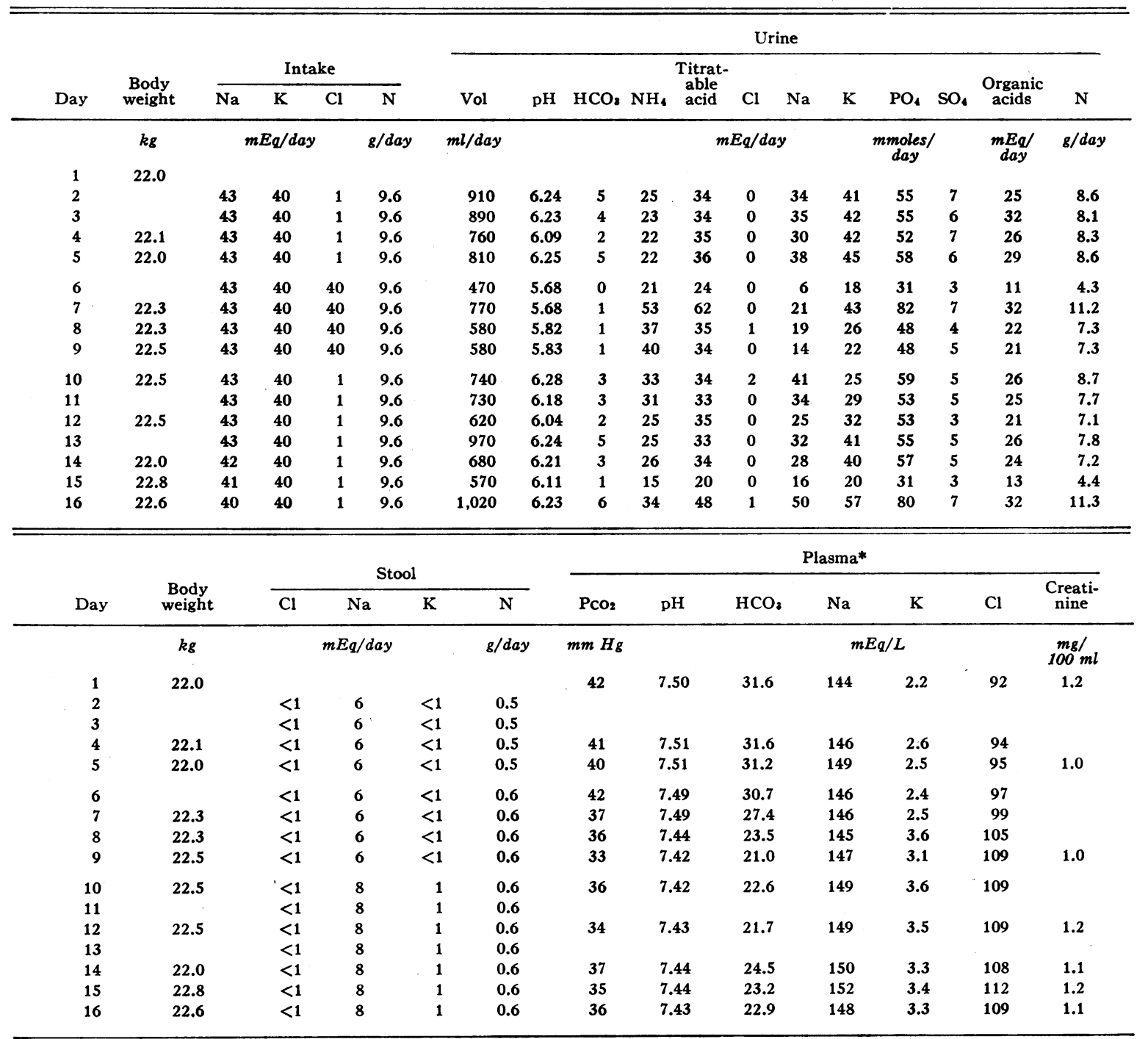

* Blood was drawn for determination at the end of each balance day.

7.53) to $22.1 \mathrm{mEq}$ per $\mathrm{L}(\mathrm{pH} 7.44)$. It can be calculated that an average of 40 of the $75 \mathrm{mEq}$ of hydrogen retained during this period was buffered outside the chloride space. Acid excretion did not return to control levels until 3 days after the period of acid feeding, leading to a further loss of acid that averaged $31 \mathrm{mEq}$; this loss of acid was accompanied by a rise in mean plasma bicarbonate concentration of $1.4 \mathrm{mEq}$ per $\mathrm{L}$ to a final level of 23.5, a value slightly higher than the mean control level.
Sodium and potassium. During the administration of hydrochloric acid there was a retention of sodium that averaged $68 \mathrm{mEq}$ (range, 41 to 97 $\mathrm{mEq}$ ), and of potassium that averaged $51 \mathrm{mEq}$ (range, 38 to $74 \mathrm{mEq}$ ). During the period after acid feeding, mean sodium balance was $-7 \mathrm{mEq}$ and mean potassium balance was $+33 \mathrm{mEq}$. There were no significant changes in plasma sodium concentration. Mean plasma potassium concentration increased from 2.6 to a final level of $3.6 \mathrm{mEq}$ per L. 
TABLE II

Cumulative balances during administration of hydrochloric acid to alkalotic dogs ingesting a diet containing neutral sodium and potassium phosphate*

\begin{tabular}{|c|c|c|c|c|c|c|c|c|c|c|c|c|c|}
\hline & \multirow[b]{3}{*}{ Dog } & \multirow[b]{3}{*}{ Days } & \multirow{2}{*}{\multicolumn{2}{|c|}{ Weight }} & \multirow{2}{*}{\multicolumn{6}{|c|}{ External balance }} & \multicolumn{3}{|c|}{ Internal balance } \\
\hline & & & & & & & & & & & \multirow{2}{*}{$\begin{array}{l}\text { Intra- } \\
\text { cellular } \\
\mathrm{Na}\end{array}$} & \multirow{2}{*}{$\begin{array}{c}\text { Intra- } \\
\text { cellular } \\
\mathbf{K}\end{array}$} & \multirow{2}{*}{$\underset{\mathrm{vol}}{\mathrm{ECF}}$} \\
\hline & & & Initial & Final & $\begin{array}{l}\Delta \text { Net } \\
\text { acidt }\end{array}$ & $\mathrm{Na}$ & $\mathbf{K}$ & $\mathbf{K n} \ddagger$ & $\mathrm{Cl}$ & $\mathbf{N}$ & & & \\
\hline & & & \multicolumn{2}{|c|}{ kg } & $m E_{q}$ & \multicolumn{4}{|c|}{$m E q$} & $g$ & \multicolumn{2}{|c|}{$m E_{q}$} & $L$ \\
\hline $\mathrm{HCL}$ & 940 & 5 & 16.3 & 167 & +106 & +41 & +74 & +63 & +179 & +4.0 & -61 & +70 & +0.6 \\
\hline \multirow[t]{4}{*}{ administration } & 958 & 4 & 18.7 & 18.9 & +106 & +48 & +38 & +32 & +144 & +2.2 & -51 & +33 & +0.6 \\
\hline & 960 & 5 & 22.8 & 23.4 & +97 & +81 & +43 & +31 & +183 & +4.5 & -50 & +38 & +0.8 \\
\hline & 966 & 5 & 24.2 & 24.8 & +124 & +97 & +51 & +46 & +183 & +1.8 & -30 & +45 & +0.6 \\
\hline & 970 & 4 & 22.1 & 22.5 & +87 & +74 & +49 & +40 & +150 & +3.4 & -21 & +44 & +0.6 \\
\hline \multirow[t]{5}{*}{ Postacid period } & 940 & 7 & 16.7 & 17.0 & +83 & -17 & +69 & +42 & -16 & +10.0 & +2 & +67 & -0.1 \\
\hline & 958 & 7 & 18.9 & 19.0 & +13 & -24 & +15 & -4 & -21 & +7.0 & +7 & +14 & -0.2 \\
\hline & 960 & 7 & 23.4 & 23.4 & +54 & +4 & +9 & -18 & -21 & +9.9 & +4 & +8 & 0 \\
\hline & 966 & 3 & 24.8 & 24.6 & -22 & +6 & +44 & +29 & -4 & +5.5 & +7 & +43 & +0.1 \\
\hline & 970 & 7 & 22.5 & 22.5 & +25 & -5 & +27 & +11 & -9 & +6.0 & -5 & +26 & -0.1 \\
\hline
\end{tabular}

* Neutral phosphate $=4 \mathrm{HPO} / 1 \mathrm{H}_{2} \mathrm{HO}_{4}$

$\dagger$ Cumulative $\Delta$ net acid represents the rise in renal excretion above the mean level of excretion observed during the 4 to 6 days preceding administration of $\mathrm{HCl}$.

$\ddagger \mathbf{K} \mathbf{n}=\mathbf{K}$ corrected for $\mathbf{N}$.

ECF = extracellular fluid.

Chloride and ECF volume. Mean plasma chloride concentration increased (from 93 to $113 \mathrm{mEq}$ per L) in association with a retention of chloride that averaged $168 \mathrm{mEq}$ (range, 144 to $183 \mathrm{mEq}$ ). Plasma chloride did not change significantly in the period after acid administration, and the urine remained essentially chloride free throughout the entire study. Calculated ECF volume expanded by $0.6 \mathrm{~L}$ during the study, essentially all of the increase occurring during the period of hydrochloric acid administration.

Miscellaneous. Urinary phosphațe excretion, measured in all dogs, and organic acid and sulfate excretion, measured in two dogs, did not change significantly during the study. Body weight increased by a mean of $0.5 \mathrm{~kg}$. There were no significant changes in plasma creatinine concentration. Nitrogen balance averaged $+10.9 \mathrm{~g}$. Mean

TABLE III

Influence of electrolyte content of the diet on amount of hydrochloric acid required to correct metabolic alkalosis

\begin{tabular}{|c|c|c|c|c|c|c|c|c|}
\hline \multirow[b]{2}{*}{ Type of study } & \multirow[b]{2}{*}{ Dog } & \multirow[b]{2}{*}{ Weight } & \multirow{2}{*}{$\underset{\text { tered }}{\text { HCL }}$} & \multicolumn{5}{|c|}{$\mathrm{Plasma}_{\mathrm{HCO}}$} \\
\hline & & & & Control & Alkalotic & $\underset{H C L}{\text { End of }}$ & $\begin{array}{l}\text { Post- } \\
\text { HCL }\end{array}$ & $\triangle \mathrm{HCO}_{\mathbf{3}} *$ \\
\hline \multirow{3}{*}{$\begin{array}{l}\text { Protocol IA } \\
\text { Diet } \\
\text { containing } \\
\mathrm{Na} \text { and K } \\
\text { phosphate }\end{array}$} & & $\mathrm{kg}^{\prime}$ & mmoles & & & $m E q / L$ & & \\
\hline & $\begin{array}{l}940 \dagger \\
958 \dagger \\
960 \\
966 \dagger \\
970 \dagger\end{array}$ & $\begin{array}{l}16.3 \\
18.7 \\
22.8 \\
24.2 \\
22.1\end{array}$ & $\begin{array}{l}195 \\
156 \\
195 \\
195 \\
156\end{array}$ & $\begin{array}{l}24.7 \\
21.6 \\
22.8 \\
23.1 \\
21.0\end{array}$ & $\begin{array}{l}40.0 \\
32.5 \\
30.8 \\
32.3 \\
31.5\end{array}$ & $\begin{array}{l}21.8 \\
22.5 \\
22.2 \\
23.1 \\
21.0\end{array}$ & $\begin{array}{l}23.0 \\
23.8 \\
24.2 \\
23.6 \\
23.1\end{array}$ & $\begin{array}{l}-17.0 \\
-8.7 \\
-\quad 6.6 \\
-8.7 \\
-8.4\end{array}$ \\
\hline & Mean & 20.8 & 179 & 22.6 & 33.4 & 22.1 & 23.5 & -9.9 \\
\hline \multirow[t]{2}{*}{$\begin{array}{c}\text { Protocol IB } \\
\text { Na and K } \\
\text { phosphate } \\
\text { withdrawn } \\
\text { from diet }\end{array}$} & $\begin{array}{l}940 \dagger \\
947 \\
958 \dagger \\
967 \\
966 \dagger \\
970 \dagger \\
959\end{array}$ & $\begin{array}{l}16.0 \\
18.1 \\
19.2 \\
18.7 \\
22.1 \\
19.0 \\
25.5\end{array}$ & $\begin{array}{r}118 \\
117 \\
94 \\
96 \\
99 \\
74 \\
93\end{array}$ & $\begin{array}{l}21.3 \\
21.9 \\
24.7 \\
24.3 \\
23.1 \\
22.8 \\
23.8\end{array}$ & $\begin{array}{l}30.2 \\
28.8 \\
35.2 \\
34.1 \\
33.6 \\
32.7 \\
31.5\end{array}$ & $\begin{array}{l}20.2 \\
19.3 \\
22.7 \\
22.4 \\
21.4 \\
21.8 \\
22.5\end{array}$ & $\begin{array}{l}20.2 \\
19.5 \\
22.3 \\
23.1 \\
22.8 \\
22.3 \\
22.6\end{array}$ & $\begin{array}{r}-10.0 \\
-9.3 \\
-12.9 \\
-11.0 \\
-10.8 \\
-10.4 \\
-8.9\end{array}$ \\
\hline & Mean & 19.8 & 99 & 23.1 & 32.3 & 21.5 & 21.8 & -10.5 \\
\hline
\end{tabular}

* $\triangle \mathrm{HCO}_{2}=$ decrease in bicarbonate from the alkalotic to the end of the post- $\mathrm{HCl}$ period.

$\dagger$ Paired studies. 
plasma unmeasured anion concentration decreased by $5 \mathrm{mEq}$ per $\mathrm{L}$ during correction of alkalosis.

Protocol IB. Hydrochloric acid was administered after withdrawal of sodium and potassium phosphate from the diet.

1) Acid administration immediately after withdrawal of sodium and potassium phosphate (five dogs). Figure 2 shows a representative study in which sodium and potassium phosphate were withdrawn from the diet of an alkalotic dog and hydrochloric acid was fed immediately thereafter. Acid-base data for all studies of this type are shown in Table III (i.e., the first five dogs listed under Protocol IB).

Acid-base. A considerably smaller quantity of hydrochloric acid was required to correct the alkalosis in this study than in the previous study in which sodium and potassium phosphate were present in the diet (Protocol IA). An average of 105 mmoles (range, 94 to 118 mmoles) of acid was required to decrease plasma bicarbonate concentration from $32.4 \mathrm{mEq}$ per $\mathrm{L}(\mathrm{pH} 7.53)$ to

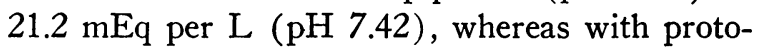
col IA, 179 mmoles (range, 156 to 195 mmoles) was required to produce a virtually identical fall in bicarbonate concentration. It should be noted that body weights were comparable in both groups and that four of the studies were randomly paired.

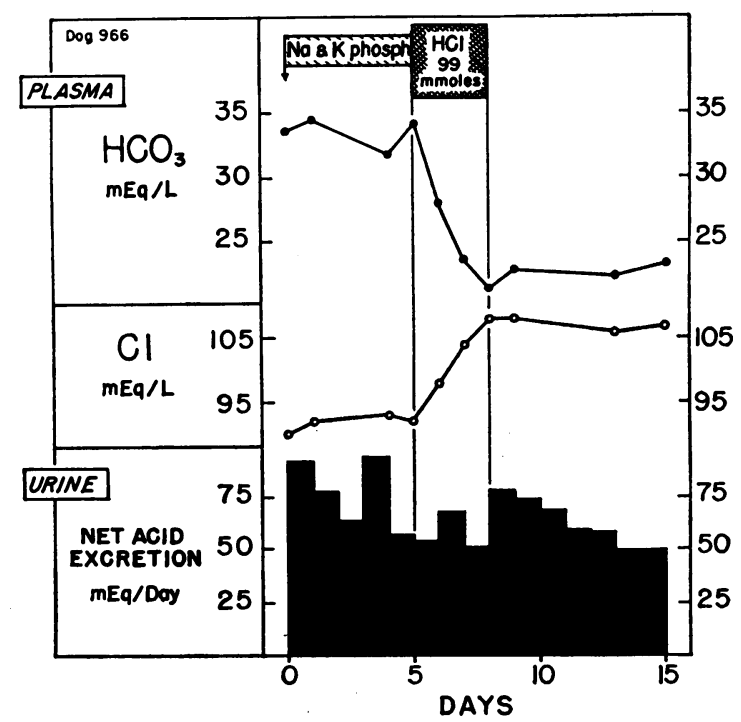

FIG. 2. EFFECTS OF ADMINISTERING HYDROCHLORIC ACID AND CONCOMITANTLY WITHDRAWING NEUTRAL SODIUM AND POTASSIUM PHOSPHATE FROM THE DIET OF AN ALKALOTIC DOG.
In contrast to Protocol IA, acid excretion did not increase in the present study. Instead, acid excretion promptly decreased to, and ultimately stabilized at, a value $15 \mathrm{mEq}$ per day lower than that of the period preceding acid administration. Excretion remained at this lower value throughout the period after acid feeding, but plasma bicarbonate concentration and $\mathrm{pH}$ stabilized at normal levels.

Sodium and potassium. In contrast to the retention of sodium and potassium observed in Protocol IA, there was a slight loss of each of these cations, external balance of sodium averaging $-22 \mathrm{mEq}$ and of potassium $-29 \mathrm{mEq}$. Plasma sodium concentration remained normal, and plasma potassium concentration was virtually unchanged from its previous value of $2.8 \mathrm{mEq}$ per L.

Chloride and ECF volume. Mean plasma chloride concentration rose from 94 to $109 \mathrm{mEq}$ per L by the end of hydrochloric acid administration. Over this interval the urine was virtually chloride free. In the period after acid administration plasma chloride concentration did not change significantly. In three dogs the urine remained chloride free during this period, but in two dogs (those given the largest amounts of hydrochloric acid, i.e., 118 and 117 mmoles) there were small daily losses in the urine that resulted in negative balances of -27 and $-42 \mathrm{mEq}$, respectively. The calculated values for ECF volume increased by an average of $0.1 \mathrm{~L}$ during the study.

2) Hydrochloric acid administration 7 days after withdrawal of sodium and potassium phosphate (two dogs). This study was carried out to dissociate the effects of sodium and potassium phosphate withdrawal from those of hydrochloric acid administration (dogs 959 and 970). Data on acid administration and plasma bicarbonate concentration for both studies are shown in Table III.

Acid-base. Upon withdrawal of sodium and potassium phosphate from the diet, daily net acid excretion decreased by 15 and $13 \mathrm{mEq}$. Alkalosis persisted, but plasma bicarbonate concentrations decreased from 33.8 and $36.9 \mathrm{mEq}$ per $\mathrm{L}$ to 31.5 and $32.7 \mathrm{mEq}$ per L, respectively. After the new steady state of alkalosis had been achieved, the administration of hydrochloric acid induced no significant change in daily net acid excretion. The cumulative excretion of $+59 \mathrm{mEq}$ in one 
dog (no. 959) and $-55 \mathrm{mEq}$ in the other (no. 970) at the end of the study was due almost entirely to minor variations in daily acid excretion during the period after acid feeding.

Apparently, then, the withdrawal of sodium and potassium phosphate rather than the administration of hydrochloric acid was responsible for the reduction in daily net acid excretion observed in the studies in which these maneuvers were performed simultaneously. Since plasma bicarbonate concentration achieved a new steady state despite the reduction in daily net acid excretion, it would appear that the decreased acid excretion resulted from a fall in endogenous acid production. It can be estimated that for the seven dogs studied with Protocol IB a mean of 57 of the 99 mmoles of administered acid was buffered outside the extracellular space.

Miscellaneous. Body weight and plasma creatinine concentration did not change significantly in any of the seven dogs. Mean nitrogen balance was slightly positive (average, $+6.6 \mathrm{~g}$ ). Plasma unmeasured anion concentration decreased by a mean of $4 \mathrm{mEq}$ per $\mathrm{L}$ during correction of alkalosis. Urinary sulfate and organic acid excretions (measured in three dogs) were essentially constant throughout the study.

\section{Protocol II: nitric acid to alkalotic dogs}

After the induction of alkalosis plasma electrolyte composition was virtually identical to that of the animals used in Protocol I. Balance studies were not carried out during induction of alkalosis, since previous studies $(4,5)$ as well as balance data for the dogs studied with Protocol I provided adequate information on the magnitude of the electrolyte loss (i.e., a moderate potassium and chloride loss with little or no sodium deficit). A representative study (no. 930) is presented in Figure 3, and electrolyte balance data for all studies of this type are shown in Table IV.

Acid-base (Figure 4). Administration of 55 to 58 mmoles per day of nitric acid induced a fall in mean plasma bicarbonate concentration from 33.4 $\mathrm{mEq}$ per $\mathrm{L}(\mathrm{pH} 7.55)$ to a nadir of $25.0 \mathrm{mEq}$ per $\mathrm{L}(\mathrm{pH} 7.48)$. These latter values for bicarbonate and $\mathrm{pH}$, which were reached on the second or third day of acid administration, were significantly higher $(p<0.01)$ than the mean control values of $21.9 \mathrm{mEq}$ per $\mathrm{L}$ and $\mathrm{pH} 7.43$; in none of the

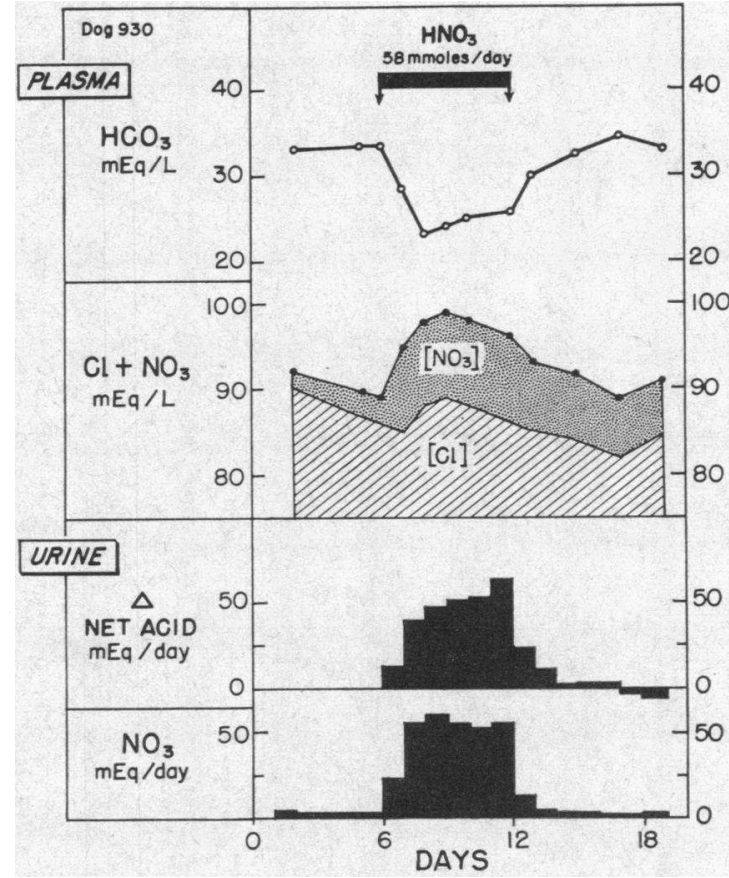

Fig. 3. EFFECTS OF ADMINISTERING NITRIC ACID TO AN ALKALOTIC DOG INGESTING A DIET CONTAINING NEUTRAL SODIUM AND POTASSIUM PHOSPHATE. The amount of nitric acid administered was far in excess of the amount of hydrochloric acid required to correct alkalosis (see Figure 1).

animals was plasma bicarbonate concentration or $\mathrm{pH}$ fully restored to normal. Despite the continued administration of nitric acid for an additional 3 to 4 days, plasma bicarbonate concentration increased slightly. Within 5 days after acid feeding had been discontinued, bicarbonate concentration rose to, and stabilized at, a mean of $34.4 \mathrm{mEq}$ per $\mathrm{L}$ ( $\mathrm{pH} 7.54$ ), a value not significantly different from that of the period before acid feeding.

Mean urine $\mathrm{pH}$ decreased from 6.1 during the period before acid administration to 5.6 by the fourth day of nitric acid administration. Concomitantly, mean net acid excretion progressively increased so that by the fifth and sixth days of acid administration, at a time when plasma bicarbonate concentration averaged $27.0 \mathrm{mEq}$ per $\mathrm{L}(\mathrm{pH}$ $7.50)$, the daily increment in acid excretion approximated the daily acid load. Most of this increment was due to an increase in ammonium excretion. Within 3 to 4 days after discontinuing nitric acid mean urinary net acid excretion and 
TABLE IV

Cumulative balances during administration of nitric acid (58 mmoles/day) to alkalotic dogs ingesting a diet containing neutral sodium and potassium phosphate

\begin{tabular}{|c|c|c|c|c|c|c|c|c|c|c|c|c|c|}
\hline & \multirow[b]{2}{*}{ Dog } & \multirow[b]{2}{*}{ Days } & \multicolumn{2}{|c|}{ Weight } & \multicolumn{5}{|c|}{ External balance } & \multirow{2}{*}{$\underset{\text { vol }}{\mathrm{ECF}}$} & \multicolumn{3}{|c|}{$\Delta$ Renal excretion* } \\
\hline & & & Initial & $\overline{\text { Final }}$ & $\mathrm{Na}$ & $\mathrm{K}$ & $\mathbf{K n}$ & $\overline{\mathrm{Cl}}$ & $N$ & & $\begin{array}{l}\text { Net } \\
\text { acid }\end{array}$ & $\mathrm{NO}_{3}$ & $\mathrm{Cl}$ \\
\hline Nitric acid & $\begin{array}{l}919 \\
920 \\
936 \\
930 \\
928\end{array}$ & $\begin{array}{l}6 \\
6 \\
6 \\
6 \\
6\end{array}$ & $\begin{array}{l}16.1 \\
20.3 \\
17.2 \\
13.1 \\
20.2\end{array}$ & $\begin{array}{l}16.0 \\
20.4 \\
16.9 \\
12.9 \\
20.2\end{array}$ & $\begin{array}{l}+13 \\
-28 \\
+8 \\
-37 \\
-21\end{array}$ & $\begin{array}{l}\quad m \\
-37 \\
+2 \\
-19 \\
-19 \\
-34\end{array}$ & $\begin{array}{l}-45 \\
-25 \\
-43 \\
-36 \\
-43\end{array}$ & $\begin{array}{l}-15 \\
-12 \\
-15 \\
-18 \\
-13\end{array}$ & $\begin{array}{r}g \\
+3.0 \\
+10.0 \\
+9.0 \\
+\quad 6.3 \\
+3.6\end{array}$ & $\begin{array}{c}L \\
0 \\
-0.1 \\
-0.1 \\
-0.2 \\
0\end{array}$ & $\begin{array}{l}+274 \\
+241 \\
+178 \\
+267 \\
+240\end{array}$ & $\begin{array}{l}m E q \\
+258 \\
+246 \\
+262 \\
+286 \\
+280\end{array}$ & $\begin{array}{l}+11 \\
+12 \\
+5 \\
+13 \\
+10\end{array}$ \\
\hline Postacid & $\begin{array}{l}919 \\
920 \\
936 \\
930 \\
928\end{array}$ & $\begin{array}{l}7 \\
8 \\
7 \\
7 \\
9\end{array}$ & $\begin{array}{l}16.0 \\
20.4 \\
16.9 \\
12.9 \\
20.2\end{array}$ & $\begin{array}{l}15.9 \\
20.6 \\
16.8 \\
13.0 \\
20.3\end{array}$ & $\begin{array}{l}-19 \\
+20 \\
+4 \\
+19 \\
+\end{array}$ & $\begin{array}{l}-16 \\
-6 \\
-10 \\
+6\end{array}$ & $\begin{array}{l}-19 \\
-25 \\
-12 \\
-7\end{array}$ & $\begin{array}{l}-8 \\
=3 \\
=5 \\
-4\end{array}$ & $\begin{array}{r}+0.9 \\
+\quad 7.0 \\
+0.8 \\
+4.8\end{array}$ & $\begin{array}{c}0 \\
+0.1 \\
0 \\
+0.1\end{array}$ & 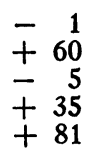 & $\begin{array}{l}+25 \\
+22 \\
+19 \\
+14 \\
+13\end{array}$ & $\begin{array}{r}+3 \\
+1 \\
\pm 5 \\
+2 \\
0\end{array}$ \\
\hline
\end{tabular}

* Cumulative $\Delta$ excretion represents the rise in renal excretion above the mean level observed during the 4 to 6 days preceding administration of $\mathrm{HNO}_{3}$

$\dagger$ Stool specimens lost.

urine $\mathrm{pH}$ both returned to the levels preceding acid ingestion.

In four of the five dogs from 83 to $95 \%$ of the acid load was recovered, with an average of 37 of the administered 337 mmoles not being accounted for in the urine. In one dog (no. 936), however, the cumulative increment in acid excretion by the end of the study was equivalent to only about half of the administered acid load.

Nitrate and chloride. Mean urinary nitrate excretion increased to, and stabilized at, approximately $53 \mathrm{mEq}$ per day by the second day of acid administration and then returned to its value preceding acid feeding of approximately $3 \mathrm{mEq}$ per

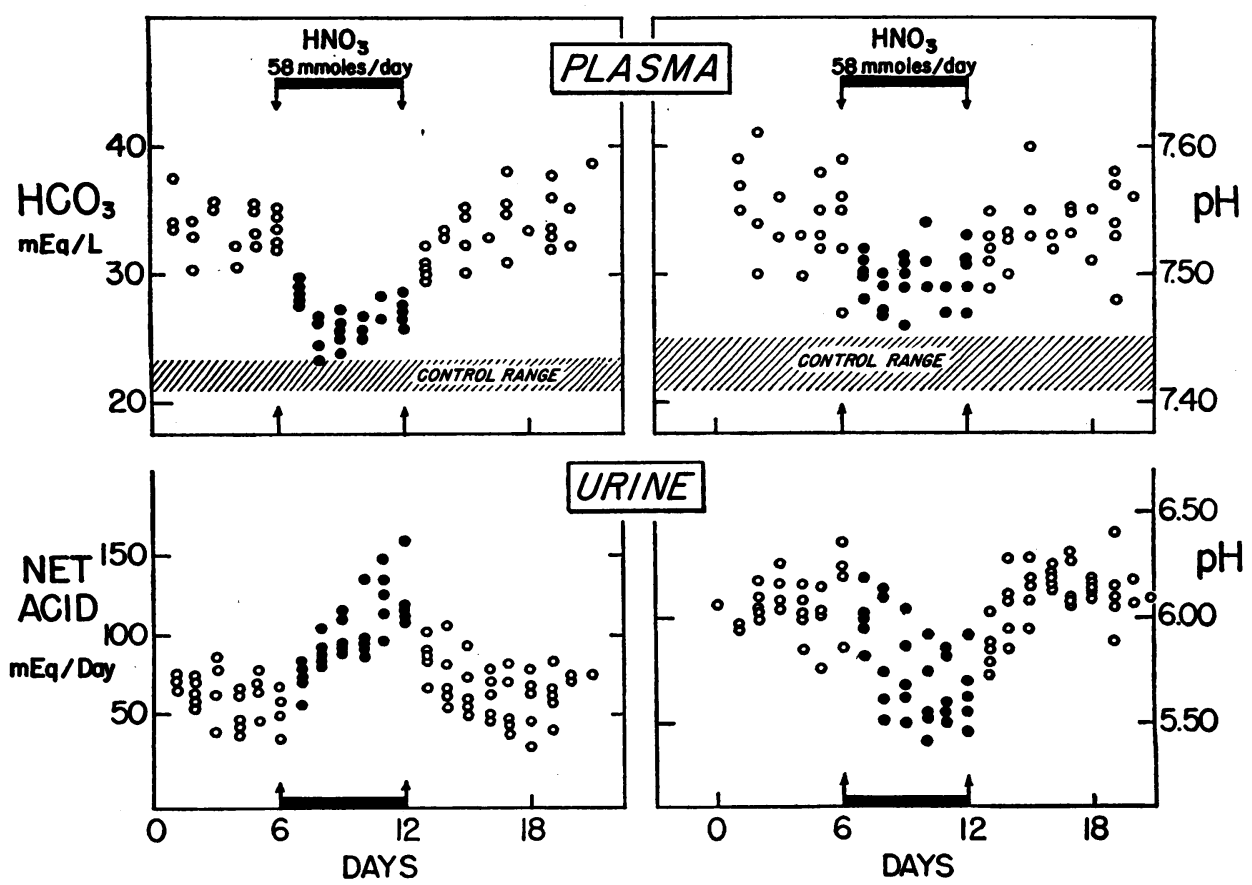

Fig. 4. Changes in plasma pH and bicarbonate concentration and in URine pH AND NET ACID EXCRETION DURING ADMINISTRATION OF NITRIC ACID TO ALKALOTIC DOGS. 
day within 2 days after acid had been discontinued. The cumulative increase in urinary nitrate excretion for the entire study averaged $285 \mathrm{mEq}$. Mean plasma nitrate concentration rose from a value of 2.5 before acid ingestion to $11.2 \mathrm{mEq}$ per $\mathrm{L}$ during nitric acid administration, and then decreased to $5.8 \mathrm{mEq}$ per $\mathrm{L}$ by the end of the period after acid feeding.

Urinary chloride excretion, usually undetectable during the control period, averaged $2 \mathrm{mEq}$ per day during the period of acid administration. Mean plasma chloride concentration decreased slowly from $89 \mathrm{mEq}$ per $\mathrm{L}$ during the period preceding acid ingestion to $85 \mathrm{mEq}$ per $\mathrm{L}$ at the end of the period after acid ingestion. It is not clear whether this decrease was due to the loss of chloride in blood specimens and urine, to a slight expansion of the extracellular fluid space related to sodium shifts, or to both.

Potassium and sodium. Mean plasma potassium concentration decreased from 2.8 to $2.6 \mathrm{mEq}$ per $L$ in association with a negative balance of approximately $-25 \mathrm{mEq}$. Neither plasma sodium concentration nor external sodium balance changed appreciably during the study.

Miscellaneous. Urinary excretion of phosphate, measured in all dogs, and of sulfate and organic acid, measured in two, did not change significantly throughout the study. Nitrogen balance was slightly positive in all studies (Table IV). Measurements of plasma creatinine concentration in three studies demonstrated no significant change. In none of the studies were there significant changes in body weight or ECF volume. Plasma unmeasured anion concentration decreased by an average of $2 \mathrm{mEq}$ per $\mathrm{L}$ during acid administration and then returned to values observed in the preacid period.

\section{Discussion}

The present studies demonstrate that administration of hydrochloric acid to an alkalotic dog ingesting sodium and potassium (as phosphate) induced prompt acidification of the urine and increased acid excretion while frank alkalosis was still present. Moreover, the magnitude of the cumulative acid loss was such that approximately half of the administered acid was diverted into the urine and correction of the alkalosis was significantly retarded. The data indicate that a shift in extracellular $\mathrm{pH}$ towards normal cannot be invoked to account for the increased acid excretion; in dogs ingesting a diet deficient in sodium and potassium, there was no renal response to hydrochloric acid despite a rapid fall in plasma $\mathrm{pH}$ and bicarbonate concentration, whereas in the dogs ingesting the cation supplement there was a marked increase in acid excretion accompanied by a slower fall in $\mathrm{pH}$ and bicarbonate concentration.

As shown in Table II, the augmented acid excretion took place in association with a virtually equivalent retention of sodium and potassium, indicating that these two events were closely linked. These data do not, of course, distinguish between a primary increase in hydrogen excretion inducing retention of sodium and potassium or a primary retention of these cations leading to increased acid excretion. On the other hand, the companion studies in which hydrochloric acid was fed with a diet free of sodium and potassium indicate that retention of cation is a prerequisite to the renal loss of acid.

As background to a consideration of these experimental findings, it should be pointed out that an animal in a steady state of hypochloremic alkalosis (as in the control period of the present study) cannot retain sodium and potassium when these ions are administered with a poorly reabsorbable anion such as phosphate (4). However, when administered with a reabsorbable anion such as chloride, these ions are promptly conserved $(4,5$, 11). In the present study, when chloride was provided as hydrochloric acid, the reabsorbable anion permitted sodium and potassium present in the diet to be retained but only at the price of leaving the phosphate anions stripped of the cations with which they had entered the body. It might be postulated, therefore, that the excretion of hydrogen took place in response to the need to maintain electroneutrality; it obviously was not directed at correcting the existing disturbances in acid-base equilibrium.

These observations are in keeping with previous acute experiments demonstrating that retention of sodium without retention of equivalent amounts of anion can induce acidification of the urine and acceleration of acid excretion in normal man and dog (12-14). Similar changes in the acid-base composition of the urine have been noted during the sodium retention induced by acute re- 
ductions in glomerular filtration rate, whether produced by aortic clamping (15) or quiet standing (16). Furthermore, it has been noted that in chronic metabolic acidosis ammonium excretion does not correlate in a quantitative fashion with the magnitude of the extracellular acidosis or with the reduction in urine $\mathrm{pH}(17,18)$; this finding has also been attributed to increased tubular reabsorption of fixed cation in the presence of obligatory anion excretion (18).

The data we have so far considered define the renal response when a hydrogen load is given with a reabsorbable anion, chloride, which the alkalotic dog can completely conserve. By contrast, the data on nitric acid allow one to examine the response to a hydrogen load given with a poorly reabsorbable anion. When nitric acid was administered to an animal ingesting sodium and potassium, plasma bicarbonate concentration decreased but did not return to normal values despite the administration of considerably more acid than in the previous hydrochloric acid studies. Furthermore, when nitric acid was discontinued, bicarbonate concentration promptly returned to its initial alkalotic level. Despite the persistence of systemic alkalosis throughout the period of acid feeding, acid excretion rose and ultimately nearly all of the administered acid was recovered in the urine. In contrast to the hydrochloric acid experiments there was no retention of sodium or potassium; instead, increased excretion of hydrogen occurred in parallel with an increase in excretion of nitrate. It would thus appear that obligatory excretion of the poorly reabsorbable anion, rather than retention of cation, was responsible for the diversion of acid into the urine.

From a consideration of the data in the hydrochloric and nitric acid experiments we suggest that the demand for sodium conservation, the reabsorbability of available anions, and the extent to which potassium and hydrogen can meet the need for cation exchange were the determinants of acid excretion. The excretion of acid did not depend either on the state of body potassium stores or on the acid-base status of the organism as reflected by extracellular $\mathrm{pH}$ or the amount of acid retained and transferred into cells. We tentatively propose, therefore, that acid excretion in uncomplicated metabolic alkalosis is not controlled by the acidity of renal tubular cells, and that cellular acidity is important only to the extent that it influences the amount of hydrogen that will be contributed when there is a demand for cation at the exchange site. An alternative formulation of these data would be that acid excretion is directly controlled by the potassium content and acidity of the renal tubular cells; this latter explanation requires that dogs receiving hydrochloric acid together with sodium and potassium phosphate have a decrease in the potassium content of renal tubular cells despite a positive body balance of potassium and that dogs receiving an electrolyte-free diet (and becoming increasingly potassium depleted) have renal potassium content restored to normal. It further requires the assumption that the dogs ingesting sodium and potassium and retaining less acid than in the electrolyte-free studies have a greater accumulation of acid in their tubular cells. There is no known physiologic basis for such behavior of the kidney, but without data on tubular composition, such a possibility cannot be excluded.

Selective depletion of hydrochloric acid as the means of inducing alkalosis was chosen because it appeared to provide the least complicated experimental model. Alkalosis can be produced in this fashion with little or no concomitant depletion of sodium or water and with only a modest potassium deficit. Furthermore, the continued administration of liberal quantities of sodium and potassium in the diet provided the opportunity for as much retention of these cations as can occur in the face of hypochloremia and chloride deficiency. In fact, the only ion denied the animals was chloride, a restriction essential to the maintenance of the alkalotic state. Obviously, the data from the present studies do not throw any light on the control of acid excretion during the alkalosis of hyperadrenalism, since it is well known that availability of chloride is not the key to the maintenance of such alkalosis, sodium chloride administration having no significant therapeutic effect.

The hypothesis proposed earlier to account for the handling of nitric acid loads could also account for the steady state excretion of endogenous acid in uncomplicated metabolic alkalosis. Since acids that are end products of metabolic activity (19) all have anions that are poorly reabsorbable (phosphate, sulfate, organic anions), the kidney is confronted each day with circumstances similar to those in the nitric acid experiments, i.e., there 
is a leak of poorly reabsorbable anion that might well induce excretion of the hydrogen ion with which it, in effect, was delivered to the extracellular fluid. This mechanism for the control of acid excretion would appear to be self-defeating since it prevents correction of alkalosis. On the other hand, if the endogenously produced hydrogen were to be retained and the alkalosis corrected, either fixed cation (i.e., sodium and potassium) would have to be lost, or the anions of the endogenous acids would have to be retained. Since these anions apparently cannot be retained, the alternative to maintenance of alkalosis is the development of a further substantial deficit of fixed cation; in all likelihood this alternative would have consequences for the organism more serious than the failure to correct alkalosis.

\section{Summary}

To examine the factors governing the renal excretion of acid in metabolic alkalosis, we administered hydrogen loads as hydrochloric or nitric acid to alkalotic dogs maintained on a chloride-free diet. The data demonstrate that, when sodium and potassium phosphate were present in the diet, the administration of hydrochloric acid led to a marked retention of sodium and potassium accompanied by an equivalent loss of acid. Acidification of the urine and increased acid excretion occurred even when plasma bicarbonate concentration and $\mathrm{pH}$ were still at frankly alkaline levels. Nearly half of the administered acid load was diverted into the urine during the restoration of normal acid-base equilibrium. On the other hand, when cation retention was prevented by removing sodium and potassium from the diet before hydrochloric acid administration, renal acid excretion did not rise, and alkalosis was fully corrected by administration of a far smaller quantity of acid.

When nitric acid was administered to alkalotic animals receiving sodium and potassium phosphate, there was also prompt acidification of the urine and an increase in acid excretion; in all other respects, however, there was a remarkable contrast to the comparable hydrochloric acid experiment. Neither sodium nor potassium was retained, and plasma bicarbonate concentration, although it decreased slightly, returned to the initial alkalotic level when acid loading was discontinued. By the completion of the study, nearly all of the administered nitrate had been recovered in the urine together with an equivalent quantity of hydrogen; it would thus appear that the obligatory excretion of nitrate, a poorly reabsorbable anion, was responsible for the increased excretion of hydrogen.

On the basis of these studies, we suggest that the demand for sodium conservation, the reabsorbability of available anions, and the extent to which potassium and hydrogen can meet the need for cation exchange determined what fraction of each acid load would be excreted. We tentatively propose that acid excretion in uncomplicated metabolic alkalosis is not controlled by the acidity of renal tubular cells and that cellular acidity is important only to the extent that it influences the amount of hydrogen which will be contributed when there is a demand for cation at the exchange site.

\section{References}

1. Berliner, R. W. Fluid and electrolyte balance in Cecil-Loeb Textbook of Medicine, 11th ed., P. B. Beeson and W. McDermott, Eds. Philadelphia and London, W. B. Saunders, 1963, p. 1291.

2. Welt, L. G. Clinical Disorders of Hydration and Acid-Base Equilibrium, 2nd. ed. Boston, Little, Brown, 1959, p. 225.

3. Polak, A., G. D. Haynie, R. M. Hays, and W. B. Schwartz. Effects of chronic hypercapnia on electrolyte and acid-base equilibrium. I. Adaptation. J. clin. Invest. 1961, 40, 1223.

4. Needle, M. A., G. J. Kaloyanides, and W. B. Schwartz. The effects of selective depletion of hydrochloric acid on acid-base and electrolyte equilibrium. J. clin. Invest. 1964, 43, 1836.

5. Gulyassy, P. F., C. Van Ypersele De Strihou, and W. B. Schwartz. On the mechanism of nitrate-induced alkalosis. The possible role of selective chloride depletion in acid-base regulation. J. clin. Invest. 1962, 41, 1850.

6. Van Slyke, D. D., and W. W. Palmer. Studies of acidosis. XVI. The titration of organic acids in urine. J. biol. Chem. 1920, 41, 567.

7. Chasson, A. L., H. J. Grady, and M. A. Stanley. Determination of creatinine by means of automatic chemical analysis. Amer. J. clin. Path. 1961, 35, 83.

8. Fiske, C. H., and Y. Subbarow. The colorimetric determination of phosphorus. J. biol. Chem. 1925, 66, 375.

9. Logsdon, E. E. A method for the determination of ammonia in biological materials on the autoanalyzer. Ann. N. Y. Acad. Sci. 1960, 87, 801.

10. Engelbrecht, R. M., and F. A. McCoy. Rapid determination of nitrate nitrogen in the presence 
of ammonia and urea. Analyt. Chem. 1956, 28, 1619.

11. Atkins, E. L., and W. B. Schwartz. Factors governing correction of the alkalosis associated with potassium deficiency; the critical role of chloride in the recovery process. J. clin. Invest. 1962, 41, 218.

12. Schwartz, W. B., R. L. Jenson, and A. S. Relman. Acidification of the urine and increased ammonium excretion without change in acid-base equilibrium: sodium reabsorption as a stimulus to the acidifying process. J. clin. Invest. 1955, 34, 673.

13. Bank, N., and W. B. Schwartz. The influence of anion penetrating ability on urinary acidification and the excretion of titratable acid. J. clin. Invest. $1960,39,1516$.

14. Sullivan, L. P., W. S. Wilde, and R. L. Malvin. Renal transport sites for $\mathrm{K}, \mathrm{H}$ and $\mathrm{NH}_{3}$. Effect of impermeant anions on their transport. Amer. J. Physiol. 1960, 198, 244.

15. Lauson, H. D., and D. D. Thompson. Effects in dogs of decrease in glomerular filtration rate on cation excretion during intravenous administration of unreabsorbable anions. Amer. J. Physiol. 1958, 192, 198.

16. Epstein, F. H., C. R. Kleeman, E. Lamdin, and M. E. Rubini. Studies of the antidiuresis of quiet standing: observations upon electrolyte and acidbase excretion during sulfate diuresis. J. clin. Invest. 1956, 35, 308.

17. Sartorius, O. W., J. C. Roemmelt, and R. F. Pitts. The renal regulation of acid-base balance in man. IV. The nature of the renal compensations in ammonium chloride acidosis. J. clin. Invest. 1949, 28, 423.

18. Schwartz, W. B., R. L. Jenson, and A. S. Relman. The disposition of acid administered to sodiumdepleted subjects: the renal response and the role of the whole body buffers. J. clin. Invest. 1954, 33, 587.

19. Relman, A. S., E. J. Lennon, and J. Lemann, Jr. Endogenous production of fixed acid and the measurement of the net balance of acid in normal subjects. J. clin. Invest. 1961, 40, 1621. 